\title{
NECROSIS OF THE FEMORAL HEAD AND HEALTH-RELATED QUALITY OF LIFE OF CHILDREN AND ADOLESCENTS
}

\section{NECROSE DA CABEÇA DO FÊMUR E QUALIDADE DE VIDA RELACIONADA À SAÚDE DE CRIANÇAS E ADOLESCENTES}

\author{
Marcos Almeida Matos ${ }^{1,2}$, Luanne Lisle dos Santos SilvaA ${ }^{2}$, Giordano Bruno Alves ${ }^{1}$, Walter Silva de Alcântara Júnior ${ }^{2}$, Davi Veiga $^{3}$ \\ 1. Escola Bahiana de Medicina e Saúde Pública, Salvador, BA, Brazil. \\ 2. Santa Casa de Misericórdia da Bahia, Salvador, BA, Brazil. \\ 3. Hospital das Clínicas da Universidade Federal da Bahia, Salvador, BA, Brazil.
}

\section{ABSTRACT}

Objective: To verify the impact of avascular necrosis of the femoral head on the quality of life of children and adolescents with Perthes disease and sickle cell disease. Methods: A comparative study including 24 children between eight and 18 years old with avascular necrosis of the femoral head secondary to Perthes disease and sickle cell disease (Group with Necrosis) and 24 children considered asymptomatic (Group without Necrosis). Clinical and sociodemographic data were collected and the PedsQL 4.0 and the Charnley score for hip dysfunction were applied. Results: There was no difference in the overall score and in any domain when comparing the Perthes group (global $=73.1$ ) and the sickle cell disease group (global $=65.9$ ). When comparing the groups with necrosis and without necrosis, the Perthes group had a lower overall score only for the Physical Functioning domain (87.5 versus 68.5); sickle cell disease group had a lower overall score (64.9 versus 79.4 ) and in the Physical Functioning (68.5 versus 87.5 ) and School Functioning (62.9 versus 73.7) domains. Conclusion: Avascular necrosis of the femoral head produces lower quality of life scores both in the global evaluation and in the domains Physical Functioning and School Functioning. Necrosis, bilateral lesion, and hip function were found to be associated with the loss of quality of life. Level of Evidence III, Sectional comparative study.

Keywords: Hip. Quality of life. Femur head necrosis.

\section{RESUMO}

Objetivo: Verificar o impacto da necrose avascular da cabeça do fêmur sobre a qualidade de vida de crianças e adolescentes com doença de Perthes e anemia falciforme. Métodos: Estudo comparativo com 24 crianças entre oito e 18 anos com necrose avascular da cabeça do fêmur secundária à doença de Perthes e à anemia falciforme (grupo com necrose) e 24 crianças consideradas assintomáticas (grupo sem necrose). Foram coletados dados clínicos e sociodemográficos e aplicado o instrumento PedsQL 4.0 e o escore de Charnley para disfunção do quadril. Resultados: Não houve diferença no escore global e em nenhum domínio comparando os grupos Perthes (global $=73,1$ ) e anemia falciforme (global = 65,9). Quando comparados os grupos sem necrose e com necrose, nota-se que o grupo Perthes tem escore inferior apenas para o domínio Capacidade Física (87,5 versus 68,5); já o grupo anemia falciforme tem escore global inferior $(64,9$ versus 79,4$)$ e também nos domínios Capacidade Física $(68,5$ versus 87,5) e Aspecto Escolar (62, 9 versus 73,7). Conclusão: A necrose avascular da cabeça do fêmur produz escores de qualidade de vida inferiores tanto na avaliação global, como nos domínios Capacidade Física e Aspecto Escolar. Foram identificadas presença de necrose, lesão bilateral e função do quadril como fatores associados à perda de qualidade de vida. Nível de evidência III, Estudo seccional comparativo.

Descritores: Quadril. Qualidade de vida. Necrose da cabeça do fêmur.

Citation: Matos MA, Silva LLS, Alves GB, Alcântara Jr WS, Veiga D. Necrosis of the femoral head and health-related quality of life of children and adolescents. Acta Ortop Bras. [online]. 2018;26(4):227-30. Available from URL: http://www.scielo.br/aob.

\section{INTRODUCTION}

Avascular necrosis of the femoral head is a chronic, degenerative and progressive disorder that mainly affects young people. ${ }^{1.2}$ Its physiopathology is characterized by the reduction or suppression of the blood supply to the femoral head with consequent loss of the trabecular architecture, causing subchondral bone collapse and secondary destructive arthropathy in up to $80 \%$ of cases. ${ }^{1,2}$ Two clinical entities in particular are recognized as a common cause of femoral head necrosis in the pediatric population: Perthes (LeggCalve-Perthes) and sickle cell disease (or anemia). ${ }^{2,3,4}$

Perthes disease represents idiopathic childhood avascular necrosis of the femoral head, and is recognized as the only primary form of this condition. ${ }^{1,2}$ Sickle cell anemia is a hematologic disease in which normal hemoglobin is genetically replaced by sickle hemoglobin. ${ }^{4}$ Vaso-occlusive phenomena are responsible for a high percentage of complications arising from sickle cell disease, including avascular

All authors declare no potential conflict of interest related to this article. 
necrosis of the femoral head itself. The prevalence of the latter in the pediatric population is around $12 \% .^{3}$ Hip involvement due to osteonecrosis in these two clinical entities involves complex, long-term treatment that often requires surgical procedures, leading to some degree of functional limitation and pain. ${ }^{1,2,3,4}$ This set of symptoms, in turn, has all the elements required to produce socioemotional disturbances and human suffering with impacts on the quality of life of individuals.

Avascular necrosis of the femoral head has traditionally had its diagnosis, treatment, and prognosis based solely on clinical orthopedic criteria and on medical imaging. ${ }^{5}$ These objective criteria, however, are not able to reflect the true impact that the condition has on the quality of life of the affected subjects. The social, economic and cultural context of patients are essential factors for defining the disease from the subjective perspective of the person who experiences it, also aiding in clinical decision making based on the expectations of the people to be treated. Nevertheless, studies assessing the impact of avascular necrosis of the femoral head on health-related quality of life (HRQOL) are still rare, especially in the pediatric population. ${ }^{3,4,6}$

In view of the above, this study aims at verifying the impact caused by avascular necrosis of the femoral head on health-related quality of life of children and adolescents, evidencing differences between patients with Perthes and sickle cell disease.

\section{MATERIALS AND METHODS}

A comparative cross-sectional study was conducted on the quality of life of children and adolescents with avascular necrosis (AVN) of the femoral head. Pediatric patients with a previous radiographic diagnosis of avascular necrosis of the femoral head monitored in the Pediatric Orthopedic outpatient department of the hospital were labeled the affected group (Group with Necrosis). The Group with Necrosis was further split into two subgroups according to the AVN etiology; therefore, subjects with Perthes disease were separated into one subgroup and those with sickle cell anemia (homozygous) were separated in another, both previously diagnosed in a conventional manner. The unaffected group (Group without Necrosis), composed of subjects who were also in the pediatric age group, were asymptomatic and came from a municipal public school in the same city.

The research study was carried out from September 2012 to October 2015, following approval by the Institutional Review Board of Hospital Santa Izabel according to protocol 89/2012. Parents or guardians of subjects who participated in the study were advised of the research objectives and procedures, and those who agreed to participate signed the Informed Consent Form (ICF).

Children with clinically and radiographically confirmed osteonecrosis of the femoral head, secondary to two exclusive etiologies, Perthes disease and sickle cell disease, were included in the group of cases (Group with Necrosis). Only those aged between eight and 18 years were included in the research project. The selected age belongs to the juvenile age group, ${ }^{4}$ with estimated ability to comprehend and answer the quality of life questionnaires used in the study (PedsQL 4.0). ${ }^{7,8}$ Subjects who did not have adequate cognition and those with neurological sequelae, other important musculoskeletal diseases, or other conditions with systemic repercussions were excluded.

The radiographic diagnosis in the Group with Necrosis was performed using anteroposterior and lateral (or frog-leg) radiographs, and the avascular necrosis was considered and classified by three specialists in Pediatric Orthopedics according to the Bucholz-Ogden criteria. ${ }^{3}$ The Group without Necrosis was formed by children considered healthy and aged between eight and 18 years, selected at a public school, whose sociodemographic characteristics were similar to those of the Group with Necrosis. All selected individuals underwent clinical orthopedic assessments to ensure absence of signs and symptoms of hip dysfunction, and no radiographic assessments were performed in this group for ethical reasons.

The sample size estimate was 12 subjects per group, calculated to detect a difference of 10 points, considering a standard deviation of 17.1 for quality of life, ${ }^{4} 5 \%$ alpha errors with $90 \%$ test power and estimated loss of $10 \%$. The participants were divided into two groups, called Group without Necrosis and Group with Necrosis, and the Group with Necrosis was subdivided into two others, composed of 12 individuals each. These subgroups represented 12 children with Perthes disease (Perthes Group) and 12 children with sickle cell disease (Sickle Cell Group). For this reason, 24 subjects were selected for the Group without Necrosis in order to match the number of participants in both groups (with and without necrosis).

After selection and inclusion, all subjects participating in the study had their clinical and sociodemographic data collected through a standardized collection instrument for the study that contained information regarding age, sex, weight, height, race (self-defined), origin, schooling (in years of study), etc. The following questionnaires were also applied: PedsQL 4.0 to assess Quality of Life in the studied age groups;, $;, 8,9$ and the Charnley-modified hip score to assess hip dysfunction. ${ }^{10}$ PedsQL 4.0 was used following authorization from the Research Trust in the Brazilian Portuguese version specifically developed for the juvenile population, with defined and validated intervals. ${ }^{9}$

The Charnley-modified Hip Score was used for quantitative and qualitative assessment of the state of the hip joint. ${ }^{10}$ This score assess range of motion, level of pain and gait, totaling 18 points in a clinically normal hip, with lower scores indicating hip dysfunction. Although this score was designed for adults, it has already been tested effectively in the pediatric population. ${ }^{10,3,4}$

The PedsQL 4.0 questionnaire is a widely divulged instrument for assessing the quality of life of children and adolescents, using questionnaires for ages ranging from 8 to 12 and from 13 to 18 years. ${ }^{7,8,9}$ All children were assessed and had their quality of life quantified by the PedsQL 4.0 instrument. PedsQL 4.0 can be self-completed by research subjects, but the authors decided to have completion and collection take place in the form of an interview, due to the low socioeconomic and educational level expected for the two groups. ${ }^{4,7,8,9}$

Answers based on the items of the PedsQL 4.0 questionnaire scales are classified as follows: Never, Almost never, Sometimes, Often, and Almost always. However, for the quantitative analysis these answers were reclassified into numerical values $(100,75,50,25$, 0 , respectively). Thus, the value obtained for each scale resulted from the arithmetic mean of the individual questions. The analysis of Health-Related Quality of Life (HRQL) was interpreted based on the values achieved: the higher the value, the better the quality of life and vice versa. ${ }^{7.8 .9}$

The descriptive presentation of continuous data in mean and standard deviation was used for statistical analysis, while discrete variables were presented in frequency. To compare the variables between the two main groups (patient with or without AVN of the femoral head) we used the chi-square test for discrete variables and the t-test for continuous variables. For the comparison between the three groups (without necrosis, Perthes and sickle cell disease) we used analysis of variance with Tukey's post-hoc test. When factors associated with quality of life were identified in the univariate analysis, a multivariate analysis was performed by logistic regression in search of confounding factors. 


\section{RESULTS}

The study sample showed itself to be homogeneous in all the sociodemographic aspects analyzed, except in the Charnley score and in the classification of necrosis, which, as they are variables related to the presence of necrosis, were different in the intergroup comparison (Table 1).

Two types of comparisons were made with the results obtained for the quality of life assessment. The first was between the three groups, namely Group without Necrosis, Perthes Group and Sickle Cell Group (Table 2). This was followed by a comparison between the Group without Necrosis and the Group with Necrosis, where the latter was composed of the sum of the Perthes and Sickle Cell groups (Table 3). No multivariate evaluation was performed in the first analysis because of the low statistical power, whereas in the second comparison, the sum of the last two groups conferred sufficient power to create the multivariate models.

There was no statistically significant difference in the overall score and in any scale when we compared the Perthes group to the group with sickle cell disease. We when compare the two groups with the control group it can be noted that the Perthes group has a lower score only for the Physical Functioning scale; the sickle cell group has a lower overall score and lower scores also in the Physical Functioning and School Functioning scales. See Table 2. There was a statistically significant difference between the two groups (with and without necrosis) in the overall quality of life score and in the Physical Functioning and School Functioning scales. See Table 3.

The following factors were included in the model in the multivariate analysis of physical functioning: group, sex, age, BMI, race, schooling, hip surgery, laterality, mean Charnley score and radiographic classification of necrosis. Predictors were group (0.012), hip surgery (0.104), laterality (0.010), and mean Charnley score (0.004). Group $(0.019 ;-0.466)$, laterality $(0.021 ;-0.453)$, and mean Charnley score $(<0.001 ; 0.703)$ were independent predictors in the final model.

The following factors were included in the model in the multivariate analysis of School Functioning: group, sex, age, BMI, race,

Table 1. Sociodemographic characteristics of the sample, comparing patients with and without avascular necrosis of the femoral head.

\begin{tabular}{c|c|c|c}
\hline Characteristic & $\begin{array}{c}\text { Group without necrosis } \\
\text { N or mean } \\
\text { (standard deviation) }\end{array}$ & $\begin{array}{c}\text { Group with necrosis } \\
\text { N or mean } \\
\text { (standard deviation) }\end{array}$ & P \\
\hline Age & $10.6(2.4)$ & $11.1(3.5)$ & 0.601 \\
\hline BMl & $18.4(3.9)$ & $18.5(4.2)$ & 0.970 \\
\hline Sex & & & 0.763 \\
\hline Male & 16 & 15 & \\
\hline Female & 8 & 9 & \\
\hline Race & & & 0.345 \\
\hline Black & 10 & 6 & \\
\hline Mixed-race & 11 & 16 & \\
\hline White & 3 & 2 & \\
\hline Laterality & - & 18 & \\
\hline Unilateral & - & 6 & \\
\hline Bilateral & - & $16.2(2.1)$ & $<0.001$ \\
\hline Charnley Score & 18 & & - \\
\hline Classification of & & 6 & \\
\hline Necrosis & - & 8 & \\
\hline Type I & - & 7 & \\
\hline Type II & - & 3 & \\
\hline Type III & - & & \\
\hline Type IV & & & \\
\hline & & & \\
\hline
\end{tabular}

Table 2. Quality of life scores comparing the group without necrosis to the Perthes and Sickle Cell groups with avascular necrosis of the femoral head.

\begin{tabular}{c|c|c|c|c}
\hline Quality of life & $\begin{array}{c}\text { Group without } \\
\text { necrosis mean } \\
\text { (standard } \\
\text { deviation) }\end{array}$ & $\begin{array}{c}\text { Perthes } \\
\text { group mean } \\
\text { (standard } \\
\text { deviation) }\end{array}$ & $\begin{array}{c}\text { Sickle cell } \\
\text { group mean } \\
\text { (standard } \\
\text { deviation) }\end{array}$ & P \\
\hline Total & $79.4(10.9)^{1}$ & $73.1(22.9)$ & $65.9(12.7)^{1}$ & 0.048 \\
\hline Physical Functioning & $87.5(6.9)^{2.3}$ & $68.5(31.8)^{2}$ & $65.1(19.3)^{3}$ & 0.002 \\
\hline Emotional Functioning & $65.2(15.1)$ & $75.1(27.6)$ & $67.5(13.5)$ & 0.337 \\
\hline Social Functioning & $86.9(15.1)$ & $80.8(19.4)$ & $77.9(16.8)$ & 0.279 \\
\hline School Functioning & $73.7(17.2)^{4}$ & $72.1(26.2)$ & $53.7(17.2)^{4}$ & 0.018 \\
\hline
\end{tabular}

$1=0.039 ; 2=0.019 ; 3=0.005 ; 4=0.017$.

Table 3. Quality of life scores comparing the group without necrosis to the group with avascular necrosis of the femoral head.

\begin{tabular}{c|c|c|c}
\hline Quality of life & $\begin{array}{c}\text { Group without necrosis } \\
\text { mean } \\
\text { (standard deviation) }\end{array}$ & $\begin{array}{c}\text { Group with necrosis } \\
\text { mean } \\
\text { (standard deviation) }\end{array}$ & P \\
\hline Total & $79.4(10.9)$ & $69.4(18.5)$ & 0.02 \\
\hline Physical Functioning & $87.5(6.9)$ & $66.8(25.8)$ & $<0.01$ \\
\hline Emotional & $65.2(15.1)$ & $71.2(21.6)$ & 0.26 \\
\hline Functioning & $86.9(15.1)$ & $79.4(17.8)$ & 0.12 \\
\hline Social Functioning & $73.7(17.2)$ & $62.9(23.6)$ & 0.07 \\
\hline School Functioning & & & \\
\hline
\end{tabular}

schooling, hip surgery, laterality, mean Charnley score and radiographic classification of necrosis. Predictors were group (0.001) and sex (0.034). Only group (0.008; -0.387$)$ remained as independent associated predictor in the final model.

The following factors were included in the model in the multivariate analysis of Social Functioning: group, sex. Age, BMI, race, schooling, hip surgery, laterality, mean Charnley score and radiographic classification of necrosis. BMI was the predictor (0.026).

\section{DISCUSSION}

The findings of this study demonstrated that the health-related quality of life of children and adolescents affected by avascular necrosis of the femoral head have significantly worse scores, both overall and in the Physical Functioning and School Functioning scales. The isolated analysis of patients with Perthes disease, however, differed in the quality of life scores from those whose necrosis was a result of sickle cell anemia. Perthes disease was only able to significantly decrease the Physical Functioning scale, while sickle cell disease was able to decrease the overall score as well as the Physical Functioning and School Functioning scales.

The multivariate analysis showed that patients with avascular necrosis of the femoral head had the decrease in the Physical Functioning scale directly influenced by the presence of sickle cell disease, presence of bilateral injury, and by greater hip dysfunction (Charnley score). In the case of the School Functioning scale, two factors were associated, sickle cell disease and sex, but only the presence of sickle cell disease was able to lower the score obtained. Quality of life and suffering are two variables that are usually inversely correlated. Avascular necrosis of the femoral head is a chronic condition that severely affects hip function, leading to physical limitation, pain, prolonged treatment and human suffering. ${ }^{1,2,3,5}$ These findings are consistent with studies showing that pain and function are directly associated with diminished quality of life of the pediatric population in general. ${ }^{11}$ In our results, Physical Functioning was the scale that most strongly affected quality of life, and pain 
was the characteristic that contributed most to the drop in the Chanrley hip score.

Pediatric patients with chronic diseases usually have a consistently poorer quality of life than that of the healthy juvenile population. Osteonecrosis of the femoral head is also associated with chronic diseases that have already been proven capable of producing loss of quality of life, such as sick cell anemia. ${ }^{3}$ In these diseases, children usually undergo multiple clinical and surgical treatments, which may result in marked functional loss, dissatisfaction, physical, financial and emotional strain.12,13,14

Dale et al. $2011^{15}$ assessed quality of life in 127 children and adolescents with sickle cell anemia and found an overall score of 68.6 points using PedsQL 4.0 as a measurement instrument. These authors confirmed significant loss of quality of life in sickle cell disease in all the scales studied compared to healthy subjects. Mallheiros et al. $2015^{4}$ studied the quality of life of patients with sickle cell anemia and simultaneously subjects with hip dysfunction; the results indicated an even lower overall score of around 58.57 points, and pain was present in $58.8 \%$ of patients with dysfunction. Our patients, however, provided evidence of poorer quality of life than children with sickle cell anemia. This data points to a potentially devastating role that necrosis of the femoral head may play when it appears in the course of this chronic disease, especially as it affects the physical ability of individuals and produces pain that persists for long periods of time.

Our findings also point to the confirmation that necrosis of the femoral head is capable of individually promoting loss of quality of life, even in cases regarded as less severe. Study participants who had osteonecrosis and associated sickle cell disease were among those with the worse HRQL scores, but significantly lower scores were also found in patients with Perthes disease, which is traditionally considered to be "silent" or asymptomatic after the acute phase.
The multivariate analysis also demonstrated that the presence of necrosis, bilateral disease and low hip scores, irrespective of other associated factors, were independent predictors for loss of HRQoL in the population studied.

To the best of our knowledge, there is no similar study with avascular necrosis of the femoral head in pediatric patients that can serve as a comparison. Hailer et al. conducted a health-related quality of life study in patients with Perthes disease in $2014^{6}$. Although this study was conducted in adults, the authors confirmed lower quality of life scores in this group of subjects versus the general population; this decrease was significantly different particularly in the mobility, usual activities, and pain scales.

Our study represents an original contribution to the subject of avascular necrosis of the femoral head in children, especially from the point of view of the medical assessment based on the perception of the subject. Our data allowed us to confirm the hypothesis that pediatric patients with avascular necrosis of the femoral head have lower quality of life scores than healthy children, both in the overall assessment and in the Physical Functioning and School Functioning scales. Secondarily, we also identified predictors associated with the loss of quality of life in these patients, namely presence of necrosis, bilateral injury and hip function (Charnley score).

\section{CONCLUSIONS}

Avascular necrosis of the femoral head is capable of adversely affecting the quality of life of children and adolescents with Perthes and sickle cell disease. When compared to healthy children, patients with Perthes disease have lower quality of life scores only in the Physical Functioning scale, whereas patients with sickle cell disease have a greater impact, with lower scores both overall and in the Physical Functioning and School Functioning scales.

AUTHORS' CONTRIBUTIONS: Each author made significant individual contributions to this manuscript. MAM (0000-0002-3592-986X)*: Intellectual concept of the article and drafting of the entire research project, collection and analysis of data, writing of the article and revision; LLSS (0000-0002-0745-8992** Intellectual concept of the article and drafting of the entire research project, collection and analysis of data, revision; GBA(0000-0002-9450-1513)*: Intellectual concept of the article, collection and analysis of data, writing of the article, and revision; WSAJ (0000-0001-9621-6380) * Intellectual concept of the article, collection and analysis of data, writing of the article, and revision; DV(0000-0001-7595-9011)*: Intellectual concept of the article, writing of the article, and revision. *ORCID (Open Researcher and Contributor ID).

\section{REFERENCES}

1. Wiig $\mathrm{O}$, Terjesen $\mathrm{T}$, Svenningsen $\mathrm{S}$. Prognostic factors and outcome of treatment in Perthes' disease. J Bone Joint Surg. 2008;90(10):1364-71.

2. Cheng JC, Lam TP, Ng BK. Prognosis and Prognostic Factors of Legg-Calve-Perthes Disease. J Pediatr Orthop. 2011;31(2 Suppl):147-51.

3. Matos MA, Silva LLS, Fernandes RB, Malheiros CD, Silva BVP. Avascular necrosis of the femoral head in sickle cell disease patients. Ortop Traumatol Rehabil. 2012;14(2):155-60.

4. Malheiros CD, Lisle L, Castelar M, Sá KN, Matos MA. Hip Dysfunction and Quality of Life in Patients With Sickle Cell Disease. Clin Pediatr (Phila). 2015;54(14):1354-8.

5. Zhao FC, Li ZR, Zhang NF, Wang BL, Sun W, Cheng LM, et al. Lesion size changes in osteonecrosis of the femoral head: a long-term prospective study using MRI. Int Orthop. 2010;34(6):799-804.

6. Hailer YD, Haag AC, Nilsson O. Legg-Calvé-Perthes Disease: Quality of Life, Physical Activity, and Behavior Pattern. J Pediatr Orthop. 2014;34(5):514-21.

7. Varni JW, Seid M, Rode CA. The PedsQL: measurement model for the pediatric quality of life inventory. Med Care. 1999;37(2):126-39.

8. Varni JW, Seid M, Kurtin PS. PedsQL 4.0: reliability and validity of the Pediatric Quality of Life Inventory Version 4.0 generic Core Scales in healthy and patient populations. Med Care. 2001;39(8):800-12
9. Klatchoian DA, Len CA, Terreri MT, Silva M, Itamoto C, Ciconelli RM, et al. Quality of life of children and adolescents from São Paulo: Reliability and validity of the Brazilian version of the Pediatric Quality of Life Inventory ${ }^{\top \mathrm{M}}$ version 4.0 Generic Core Scales. J Pediatr (Rio J). 2008;84(4):308-15.

10. Charnley J. The Long-term results of low-friction arthroplasty of the hip performed as a primary intervention. J Bone Joint Surg Br. 1972;54(1):61-76.

11. Fisak B, Belkin MH, Von Lehe AC, Bansal MM. The relation between health-related quality of life, treatment adherence and disease severity in a paediatric sickle cell disease sample. Child Care Health Dev. 2011;38(2):204-10.

12. Roposch A, Liu LQ, Offiah AC, Wedge JH. Functional outcomes in children with osteonecrosis secondary to treatment of developmental dysplasia of the hip. J Bone Joint Surg Am. 2011;93(24):e145.

13. Unal VS, Gulcek M, Soydan Z, Ucaner A, Yazici M. Assessment of quality of life in children after successful treatment of hip dysplasia as compared with normal controls. Saudi Med J. 2006;27(8):1212-6.

14. Krebs A, StrobI WM, Grill F. Neurogenic hip dislocation in cerebral palsy: quality of life and results after hip reconstruction. J Child Orthop. 2008;2(2):125-131.

15. Dale JC, Cochran CJ, Roy L, Jernigan E, Buchanan GR. Health-related quality of life in children and adolescents with sickle cell disease. J Pediatr Health Care. 2011;25(4):208-15 